\title{
Mycorrhizal Status of Two Hawaiian Plant Species (Asteraceae) in a Tropical Alpine Habitat: The Threatened Haleakala Silversword (Argyroxiphium sandwicense subsp. macrocephalum) and the Endemic Dubautia menziesii ${ }^{1}$
}

\author{
R. E. Koske ${ }^{2,3}$ and 7. N. Gemma ${ }^{2}$
}

\begin{abstract}
Samples of roots and root-zone soil from the threatened species $A r$ gyroxipbium sandwicense subsp. macrocephalum and the endemic species Dubautia menziesii, both members of the Asteraceae, were collected in a tropical alpine area in Haleakalā National Park, Maui, Hawai' $i$, and examined for arbuscular mycorrhizal fungi (AMF). All root samples exhibited the Paris-type of mycorrhizae with arbuscules produced on hyphal coils, and all soil collections included spores of AMF. Spores of Acaulospora, Entrophospora, Glomus, and Scutellospora spp. were recovered from this site.
\end{abstract}

Arbuscular mycorrhizal fungi (AMF) form mutualistic associations with the majority of plants and are especially frequent in endemic Hawaiian species (Koske et al. 1992). These fungi are known to play a vital role in scavenging phosphorus and other nutrients from soils and providing them to plants (Read and Smith 1997). The AMF association is especially critical to plants growing in soils with low availability of phosphorus, typical of many of the volcanic soils of the Hawaiian Islands (Gemma et al. 2002). In addition, AMF have been found to confer a significant level of drought tolerance to plants (e.g., Auge 2001).

The rescue of the Haleakala silversword (Argyroxiphium sandwicense DC. subsp. macrocephalum) from near extinction in Haleakalā National Park, Maui, Hawai'i, ranks as one of the highlights of Hawaiian plant conservation (Loope and Medeiros 1995). This federally

\footnotetext{
${ }^{1}$ This research was funded in part by a Faculty Fellowship from the University of Rhode Island. Manuscript accepted 23 January 2002.

${ }^{2}$ Department of Biological Sciences, University of Rhode Island, Kingston, Rhode Island 02881.

${ }^{3}$ Corresponding author (phone: 401-874-2629; fax: 401-874-5974; E-mail: rkoske@uri.edu).
}

Pacific Science (2002), vol. 56, no. 4:423-430

(C) 2002 by University of Hawai'i Press

All rights reserved listed threatened species is endemic to a single 1000-ha area in Haleakalā National Park, occurring between 2100 and $3000 \mathrm{~m}$ above sea level (Loope and Medeiros 1995). The plants grow in nearly barren areas of loose volcanic cinder in a tropical alpine habitat. Seedling mortality is high in these sites, which are characterized by great diurnal temperature fluctuations (soil temperatures range from -5 to $60^{\circ} \mathrm{C}$ during the course of a single day), drought stress, and low plantavailable phosphorus in the soil (Goldstein et al. 1996, Gemma et al. 2002).

Because of the known benefits of AMF in such stressful environments and the remarkable recovery of the population of silverswords in this nearly barren site, we investigated the mycorrhizal status of plants of $A$. sandwicense subsp. macrocephalum growing in Haleakalā National Park. In addition, we examined Dubautia menziesii (A. Gray) D. Keck, a codominant at the site.

\section{MATERIALS AND METHODS}

Root and soil samples were collected from the Kalahaku area of Mt. Haleakalā (elevation ca. $2825 \mathrm{~m} ; 20^{\circ} 45^{\prime} \mathrm{N}, 156^{\circ} 12^{\prime} \mathrm{W}$ ) from beneath six specimens of $A$. sandwicense subsp. macrocephalum (hereafter referred to as $A$. sandwicense) (Asteraceae) in December 1998. The sampling time in this alpine site (e.g., $>1800 \mathrm{~m}$ [Carlquist 1980]) was in the wet 


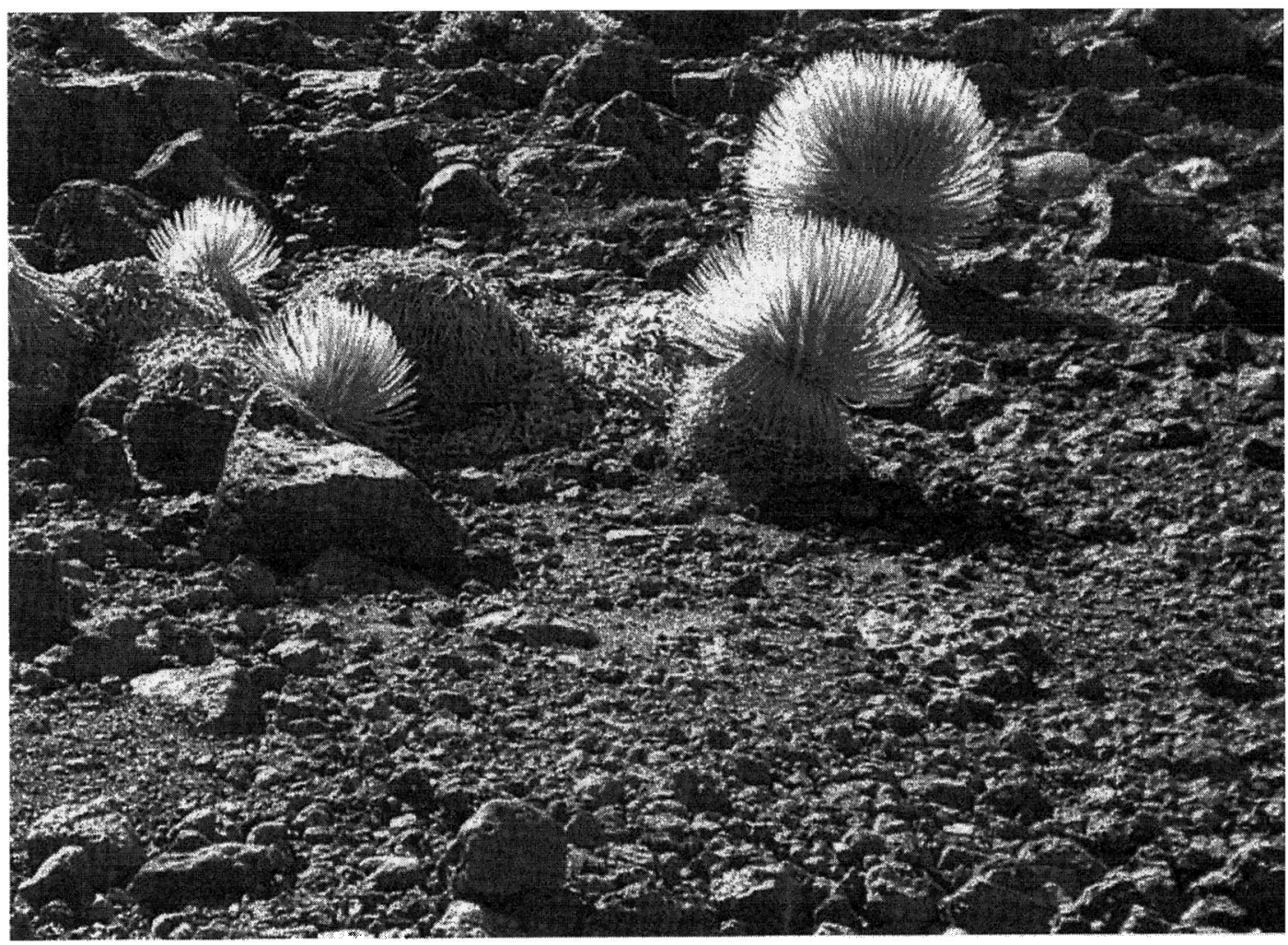

Figure 1. Habitat of Argyroxiphium sandwicense subsp. macrocephalum on Mt. Haleakalā, Maui, Hawai'i. Note low plant cover.

season that lasts from November to April (Price 1983). Care was taken to cause minimal damage to the plants (hence, root samples were small [ca. $6-10 \mathrm{~cm}$ long]). The $\mathrm{a}^{6} \overline{\mathrm{a}}$ type of lava dominated the site, and soils were composed primarily of weathered volcanic cinders. Volcanic activity had ceased several hundred years previous to the sampling. The collecting area had very low cover, and plants that were sampled were separated from other plants by $>3 \mathrm{~m}$ (Figure 1). Other species in the area included Dubautia menziesii (Asteraceae), a species endemic to the slopes and crater of Mt. Haleakalā (Wagner et al. 1990), and the indigenous Styphelia tameiameiae (Cham. \& Schlectend.) F.v. Muell. (Epacridaceae). For comparative purposes, collections also were made from isolated plants of D. menziesii (four individuals) from the same area. This species and $A$. sandwicense are closely related and hybridize spontaneously in the field (Wagner et al. 1990). All collections were taken to the laboratory at the University of Hawai'i at Mānoa on $\mathrm{O}^{6} \mathrm{ahu}$, and roots were washed, cleared, and stained with trypan blue (Koske and Gemma 1989). Soil samples were refrigerated at $4^{\circ} \mathrm{C}$ until processed to recover spores.

Stained roots were examined at $40-60 \times$ with a dissecting microscope, and portions of each root system were examined at $400 \times$ with a compound microscope. The presence of vesicles, arbuscules, hyphal coils, and internal hyphae was noted for each species. Only those species in which arbuscules were found were considered to have functional arbuscular mycorrhizae (AM) and were given an infection rating greater than 0. Extent of 
$\mathrm{AM}$ infection was quantified by assigning a mycorrhizal index (MI) value of 0 to 3 to stained roots, where 0 indicates no functional $\mathrm{AM}$ colonization, $1=$ up to $25 \%$ of root length colonized (i.e., containing arbuscules, coils, and hyphae), $2=25-75 \%$ colonized, and $3=>75 \%$ colonized (Koske et al. 1992). The MI of each species was calculated by averaging the MI of each sample of that species that was examined. Although the assessment of AM colonization of roots by the MI method is less precise than the more commonly used methods (e.g., calculation of percentage of length of root system containing AMF structures [Giovannetti and Mosse 1980]), there is little evidence that percentage of root colonization is correlated with mycorrhizal benefit. In several studies, significant increases in growth and drought tolerance resulted from inoculation with $\mathrm{AMF}$ when colonization levels were $1.5-7 \%$ of root length (e.g., Gemma and Koske 1997, Gemma et al. 1997).

To identify spores of AMF that were associated with the plants whose root systems were sampled, soil samples of ca. $500 \mathrm{~cm}^{3}$ were collected from each root zone. Spores of AMF were isolated from a $42-\mathrm{cm}^{3}$ subsample from each of the 10 collections by wet-sieving and centrifugation in $40 \%$ sucrose (Walker et al. 1982). Spores were identified by comparison with type specimens.

Spore abundance data were logtransformed (St. John and Koske 1988), and differences between AMF populations associated with the two host species were investigated by $t$ tests. Differences in the frequency of occurrence of individual species were analyzed using a modified $\chi^{2}$ test incorporating Yate's correction for continuity (Sokal and Rohlf 1981). Soil-solution phosphorus was measured (Fox and Kamprath 1970) in three of the soil samples from root zones of $A$. sandwicense. Three grams of soil was shaken in $30 \mathrm{~cm}^{3}$ of $0.01 \mathrm{M} \mathrm{CaCl}_{2}$ for $1 \mathrm{hr}$. The solution was centrifuged, and $\mathrm{PO}_{4}$ in the supernatant was determined colorimetrically using the molybdenum blue method. Angiosperm systematics and nomenclature are those of Wagner et al. (1990).

\section{RESULTS}

All six root systems of $A$. sandwicense were colonized by AMF, and spores of AMF were found in all samples. Internal hyphae were abundant in the roots as were arbuscules and hyphal coils (Figures 2, 3). MI values ranged from 1 to 2 , with a mean of 1.4. All root systems of $D$. menziesii were colonized by AMF (Figure 4), with MI values ranging from 1 to 2 (mean $=1.25)$. All mycorrhizae were of the Paris-type with arbuscules arising from hyphal coils in the cortical cells (Figure 3). Vesicles were not observed in any of the 10 samples. Soil-solution phosphorus values were $0.008,0.009$, and $0.009 \mathrm{mg}$ phosphorus per liter.

Spores of AMF were found in all root zone samples. AMF species richness (no. of species recovered/sample) ranged from 2 to 4 (mean $=3.3$ ) for $A$. sandwicense samples and 1 to 4 (mean $=2.5)$ for $D$. menziesii (Table 1$)$. Spore abundance (all AMF species) did not differ significantly between samples from the two plant species, averaging 47.6 spores per $100 \mathrm{~cm}^{3}$ soil for $A$. sandwicense and 150.0 for D. menziesii. Spores of Entrophospora infrequens Hall (Ames \& Schneider) were identified. Other AMF species appeared to be undescribed and were identified only to genus and assigned a reference number (e.g., Glomus 8156). The AMF species most frequently isolated from root zones of $A$. sandwicense were Glomus 8156 (67\% of the samples), $\mathrm{Scu}$ tellospora 8156 (67\%), Acaulospora 8156 (50\%), Acaulospora 8159 (50\%), and E. infrequens (50\%) (Table 1). Frequency of occurrence of spores in the root zone samples of $D$. menziesii was similar to that of $A$. sandwicense, except that spores of Scutellospora 8156 were isolated from only a single sample. In spore abundance, Scutellospora 8156 dominated the $A$. sandwicense samples (mean $=19.00$ spores per $100 \mathrm{~cm}^{3}$ ), and E. infrequens was dominant in the D. menziesii samples (mean $=108.25$ spores per $100 \mathrm{~cm}^{3}$ ). Variation between samples was so great that no significant differences between the spore populations of each AMF species beneath different host species were detected. 

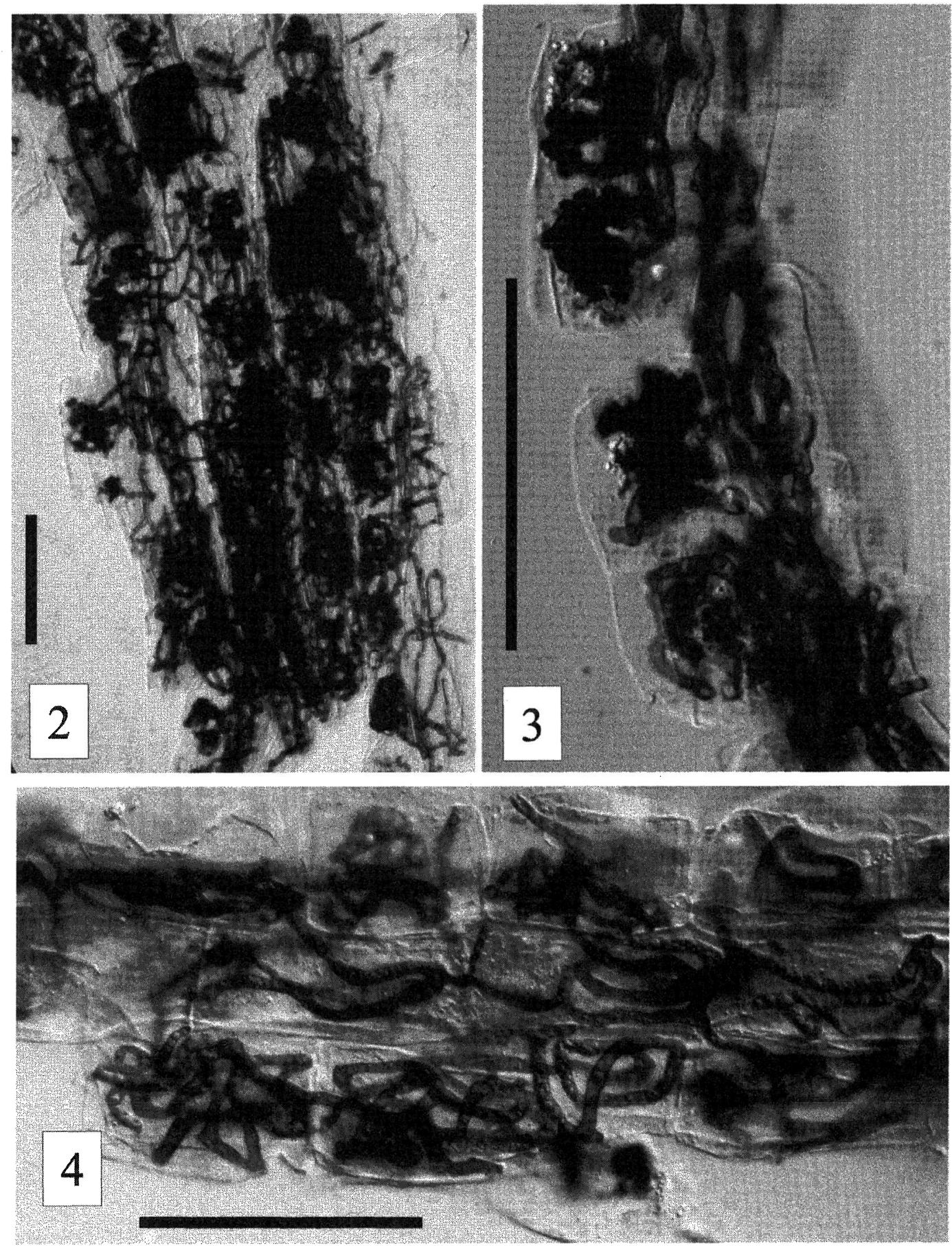

Figures 2-4. Roots of Argyroxiphium sandwicense subsp. macrocephalum and Dubautia menziesii stained for arbuscular mycorrhizal fungi. 2, A. sandwicense root with dark-staining internal hyphae and coils in the cortical cells. $3, A$. sandwicense cortical cells with four prominent arbuscules. 4, D. menziesii root with hyphal coils. Scale $=100 \mu \mathrm{m}$. 
TABLE 1

Frequency and Abundance of Spores of Arbuscular Mycorrhizal Fungi (AMF) in Root Zones of Argyroxiphium sandwicense subsp. macrocephalum and Dubautia menziesii

\begin{tabular}{|c|c|c|c|c|}
\hline \multirow[b]{2}{*}{ AMF species } & \multicolumn{2}{|c|}{$\begin{array}{l}\text { Argyroxiphium sandwicense subsp. } \\
\text { macrocephalum }(n=6)\end{array}$} & \multicolumn{2}{|c|}{ Dubautia menziesii $(n=4)$} \\
\hline & Freq.$^{a}$ & Abun. ${ }^{b}$ & Freq. & Abun. \\
\hline Acaulospora 8156 & 50 & $7.12 \pm 4.44$ & 50 & $17.00 \pm 14.37$ \\
\hline Acaulospora 8159 & 50 & $0.77 \pm 0.48$ & 50 & $17.47 \pm 15.13$ \\
\hline Entrophospora infrequens & 50 & $3.93 \pm 3.05$ & 50 & $108.25 \pm 86.79$ \\
\hline Glomus 8155 & 33 & $2.78 \pm 1.98$ & 25 & $9.53 \pm 9.53$ \\
\hline Glomus 8156 & 67 & $5.66 \pm 3.96$ & 50 & $7.13 \pm 7.13$ \\
\hline Scutellospora 8156 & 67 & $19.00 \pm 14.37$ & 25 & $1.20 \pm 1.20$ \\
\hline Scutellospora 8170 & 17 & $8.70 \pm 8.70$ & 0.0 & 0.0 \\
\hline All species & - & $47.6 \pm 15.7$ & - & $150.0 \pm 86.2$ \\
\hline
\end{tabular}

${ }^{a}$ Percentage of samples from which spores were isolated.

${ }^{b}$ Mean spore abundance per $100 \mathrm{~cm}^{3}$ of soil \pm SE.

\section{DISCUSSION}

Examination of root and soil samples from the plants on Mt. Haleakalā revealed that both $A$. sandwicense and D. menziesii are AMforming species. AM have been reported previously from other alpine habitats (e.g., Haselwandter and Read 1980), including from the tropical high mountains of Venezuela (Barnola and Montilla 1997). The latter investigators found AM in 28 of 31 species of plants growing at $3100 \mathrm{~m}$ elevation.

One other species of silversword, Wilkesia gymnoxipbium A. Gray (a species endemic to the island of Kaua ${ }^{6}$ ), and several species in the closely related genus Dubautia in the Hawaiian Islands have been examined for AM (Koske et al. 1992). All three collections of $W$. gymnoxiphium were mycorrhizal $(\mathrm{MI}=2.0)$. Dubautia ciliolata (DC.) D. Keck subsp. ciliolata, D. knudsenii Hillebr. subsp. knudsenii, D. plantaginea Gaud. subsp. magnifolia (Sherff) G. Carr, and D. scabra (DC.) D. Keck subsp. scabra also were examined, and all but the latter were always mycorrhizal. Three of six specimens of the latter species formed AM. Mean MI values for the Dubautia species ranged from 1.0 to 3.0 .

Mycorrhizae in the roots of both $A$. sandwicense and $D$. menziesii were similar in appearance and were of the Paris-type (Smith and Smith 1997). The presence of this type in the Asteraceae is unusual (Smith and Smith 1997), and the few genera in the family that have been investigated possessed only the Arum-type of mycorrhiza. Further studies are needed to evaluate the significance of the Hawaiian results.

Identification of species of AMF is difficult, but several of the species from the $\mathrm{Ha}-$ leakalā National Park collections appeared to be undescribed. Additional material is required to confirm this. None of the species from Haleakalā National Park was isolated during the only other surveys of AMF in Hawai' $i$, those made from sand dunes on the islands of Kaua'i and Hawai'i (Koske 1988, Koske and Gemma 1996). Spores of E. infrequens have been collected from San Miguel Island off the coast of southern California (Koske and Halvorson 1989), in New Zealand (as Glomus infrequens) (Hall 1977), and elsewhere in the world (e.g., Koske et al. 1997).

The soil-solution phosphorus values (0.008-0.009 mg/liter) in the collections were very low, but are typical of many natural sites in Hawai'i (Gemma et al. 2002). For comparison, highly fertile agricultural soils have soil-solution levels of ca. $0.20 \mathrm{mg}$ phosphorus per liter (Fox 1981). Of the Hawaiian plant species that have been grown in soils with levels of phosphorus comparable with those in the Haleakalā soil, AM routinely have been 
required for significant growth (Miyasaka et al. 1993, Koske and Gemma 1995, Gemma et al. 2002). When seedlings of D. scabra were grown in a greenhouse in a soil with low phosphorus, plants that were inoculated with AMF had $100 \%$ survival whereas plants without AMF had $72 \%$ mortality (Koske and Gemma 1995). Similarly, two Hawaiian species of Bidens in the same family as $A$. sandwicense were 3.3 to 5 times larger (shoots) and 6.3 to 16.6 times larger (roots) when grown in low-phosphorus Hawaiian soils in the presence of an AM fungus (Gemma et al. 2002) in comparison with nonmycorrhizal plants.

Seedlings of $A$. sandwicense typically establish from wind-dispersed seeds in the Haleakalā site in protected microsites (e.g., near larger rocks) where extremes of temperature and moisture are less than in exposed locations (Goldstein et al. 1996). The means by which AMF fungi arrive at the same sites in which the seedlings establish is not known. $\mathrm{AMF}$ are obligate symbionts, and the fungi do not grow and reproduce in the absence of a live host. However, AMF propagules can persist in the soil in the absence of live plants for 4-5 yr or more (Ferguson and Woodhead 1982, Wagner et al. 2001). Although barren sites typically have no AMF or very low populations of AMF at a depth of several centimeters (e.g., Miller 1987, Koske and Gemma 1997), viable AMF propagules are deposited on the surface (Miller 1987).

Miller's studies in the Red Desert in Wyoming (Miller 1987) of the enhanced deposition of wind-borne spores of AMF in catchments that slowed wind speed may explain how propagules of AMF (e.g., spores, hyphae, mycorrhizal root fragments) and seeds of $A$. sandwicense arrive at the sites of establishment. Wind appears to be an effective dispersal agent, and spores of $\mathrm{AMF}$ were found to be carried for up to $2 \mathrm{~km}$ by wind in arid sites in Wyoming (Warner et al. 1987). At the Haleakalā site, disturbance of wind flow by rocks probably results in deposition of seeds, propagules of AMF, fine particles, and other debris near the rocks, leading to the establishment of seedlings in these protected sites. A similar pattern of invasion of recent lava flows in Hawai'i by AMF and AM- forming species was reported previously (Gemma and Koske 1990). In those barren sites, plant and AMF propagules accumulated in the cracks in the lava, apparently dispersed by wind and animals.

Such a scenario agrees with the manner in which the Haleakalā silversword population made its recovery over the last $60 \mathrm{yr}$. The recovery, which saw an increase from ca. 4000 individuals in 1935 to ca. 65,000 in 1993 , resulted almost entirely from the use of exclosures to protect the plants from feral goats, domestic cattle, and human vandalism and theft (Loope and Medeiros 1995). Extensive field plantings were not made and no attempt was made to introduce AMF or soil containing AMF to the area (L. Loope, pers. comm.).

It would be of value to know the extent to which $A$. sandwicense is dependent upon AMF. The failure of AMF to be present at a site when seedlings emerge would likely be fatal in the abiotically stressed sites of Haleakalā National Park if $A$. sandwicense is as dependent upon $\mathrm{AMF}$ as are many of the Hawaiian species that have been tested (Myasaka et al. 1993, Koske and Gemma 1995, Miyasaka and Habte 2001, Gemma et al. 2002). Measurement of AMF populations in soil (e.g., mycorrhizal inoculum potential) in sites where A. sandwicense is established or is likely to become established may be important in understanding the low recruitment and high mortality among naturally occurring seedlings of $A$. sandwicense in Haleakalā National Park (Loope and Crivellone 1986, Loope and Medieros 1994).

\section{ACKNOWLEDGMENTS}

We greatly appreciate the support of $M$. Habte and L. Loope. We thank Forrest Star and Kim Martz for assistance in collecting samples and two reviewers for helpful comments.

\section{Literature Cited}

Auge, R. M. 2001. Water relations, drought and vesicular-arbuscular mycorrhizal symbiosis. Mycorrhiza 11:3-42. 
Barnola, L. G., and M. G. Montilla. 1997. Vertical distribution of mycorrhizal colonization, root hairs, and belowground biomass in three contrasting sites from the tropical high mountains, Mérida, Venezuela. Arct. Alp. Res. 29:206-212.

Carlquist, S. 1980. Hawaii: A natural history. 2nd ed. Pacific Tropical Botanical Garden, Lāwa'i, Hawai'i.

Ferguson, J. J., and S. H. Woodhead. 1982. Production of endomycorrhizal inoculum. Part A. Increase and maintenance of vesicular-arbuscular mycorrhizal fungi. Pages 47-54 in N. C. Schenck, ed. Methods and principles of mycorrhizal research. American Phytopathology Society, St. Paul, Minnesota.

Fox, R. L. 1981. External phosphorus requirements of crops. Pages 223-239 in R. H. Dowdy, J. A. Ryan, V. V. Volk, and D. E. Baker, eds. Chemistry in the soil environment. American Society of Agronomy, Madison, Wisconsin.

Fox, R. L., and E. J. Kamprath. 1970. Phosphate sorption isotherms for evaluating $\mathrm{P}$ requirements of soils. Soil Sci. Soc. Am. Proc. 34:902-907.

Gemma, J. N., and R. E. Koske. 1990. Mycorrhizae in recent volcanic substrates in Hawaii. Am. J. Bot. 77:1193-1200.

1997. Arbuscular mycorrhizae in sand dune plants of the North Atlantic coast of the U.S.: Field and greenhouse studies. J. Environ. Manage. 50:251-264.

Gemma, J. N., R. E. Koske, E. M. Roberts, N. Jackson, and K. De Antonis. 1997. Mycorrhizal fungi improve drought resistance in creeping bentgrass. J. Turfgrass Sci. 73:15-29.

Gemma, J. N., R. E. Koske, and M. Habte. 2002. Mycorrhizal dependency of some endemic and endangered Hawaiian plant species. Am. J. Bot. 89:337-345.

Giovannetti, M., and B. Mosse. 1980. An evaluation of techniques for measuring vesicular arbuscular mycorrhizal infection in roots. New Phytol. 84:489-500.

Goldstein, G., D. R. Drake, P. Melcher, T. W. Giambelluca, and J. Heraux. 1996. Photosynthetic gas exchange and temperature-induced damage in seedlings of the tropical alpine species Argyroxiphium sandwicense. Oecologia (Berl.) 106: 298-307.

Hall, I. R. 1977. Species and mycorrhizal infections of New Zealand Endogonaceae. Trans. Br. Mycol. Soc. 68:341-356.

Haselwandter, K., and D. J. Read. 1980. Fungal associations of roots of dominant and sub-domination plants in high-alpine vegetation systems with special reference to mycorrhiza. Oecologia (Berl.) 45:57-62.

Koske, R. E. 1988. VA mycorrhizae of some Hawaiian dune plants. Pac. Sci. 42:217229.

Koske, R. E., and J. N. Gemma. 1989. A modified procedure for staining roots to detect V-A mycorrhizas. Mycol. Res. 92:486-488.

1995. Vesicular-arbuscular mycorrhizal inoculation of Hawaiian plants: A conservation technique for endangered tropical species. Pac. Sci. 49:181-191.

- 1996. Arbuscular-mycorrhizal fungi in Hawaiian sand dunes: Island of Kauai. Pac. Sci. 50:36-45.

- 1997. Mycorrhizae and succession in plantings of beachgrass in sand dunes. Am. J. Bot. 84:118-130.

Koske, R. E., and W. L. Halvorson. 1989. Mycorrhizal associations of selected species from San Miguel Island, Channel Islands National Park, California. Pac. Sci. 43:32-40.

Koske, R. E., J. N. Gemma, and T. Flynn. 1992. Mycotrophy in Hawaiian angiosperms: A survey with implications for the origin of the native flora. Am. J. Bot. 79:853-862.

Koske, R. E., J. N. Gemma, and N. Jackson. 1997. Arbuscular mycorrhizal fungi associated with three species of turfgrass. Can. J. Bot. 75:320-332.

Loope, L. L., and C. F. Crivellone. 1986. Status of the silversword in Haleakala National Park: Past and present. Technical Report 58. Cooperative National Park Studies Unit, Department of Botany, University of Hawai'i, Honolulu.

Loope, L. L., and A. C. Medeiros. 1994. Impacts of biological invasion on the management and recovery of rare plants in 
Haleakala National Park, Maui, Hawaii. Pages 143-158 in M. Bowles and C. J. Whelan, eds. Restoration of endangered species. Cambridge University Press, Cambridge.

1995. Haleakala silversword. Pages

363-364 in E. T. LaRoe, ed. Our living resources. U.S. Department of the Interior, National Biological Survey, Washington, D.C.

Miller, R. M. 1987. Mycorrhizae and succession. Pages 205-219 in W. R. Jordan, M. E. Gilpin, and J. D. Aber, eds. Restoration ecology. Cambridge University Press, Cambridge.

Miyasaka, S. C., and M. Habte. 2001. Plant mechanisms and mycorrhizal symbiosis to increase P uptake. Commun. Soil Sci. Plant Anal. 32:1101-1147.

Miyasaka, S. C., M. Habte, and D. T. Matsuyama. 1993. Mycorrhizal dependency of two Hawaiian endemic tree species: Koa and mamane. J. Plant Nutr. 16:1339-1356.

Price, S. 1983. Climate. Pages 59-65 in R. W. Armstrong, ed. Atlas of Hawaii. 2nd ed. University of Hawai'i Press, Honolulu.

Read, D. J., and S. E. Smith. 1997. Mycorrhizal symbiosis. 2nd ed. Academic Press, London.
Smith, F. A., and S. E. Smith. 1997. Structural diversity in (vesicular)-arbuscular mycorrhizal symbioses. New Phytol. 137:373-388.

Sokal, R. R., and F. J. Rohlf. 1981. Biometry. 2nd ed. W. H. Freeman, New York.

St. John, T. V., and R. E. Koske. 1988. Statistical treatment of endogonaceous spore counts. Trans. Br. Mycol. Soc. 91:117121.

Wagner, S. C., H. D. Skipper, F. Whalley, and W. B. Bridges. 2001. Long-term survival of Glomus claroideum propagules from soil pot cultures under simulated conditions. Mycologia 93:815-820.

Wagner, W. L., D. R. Herbst, and S. H. Sohmer. 1990. Manual of the flowering plants of Hawai'i. University of Hawai' $i$ Press and Bishop Museum Press, Honolulu.

Walker, C., C. W. Mize, and H. S. McNabb. 1982. Populations of endogonaceous fungi at two locations in central Iowa. Can. J. Bot. 60:2518-2529.

Warner, N. J., M. F. Allen, and J. A. MacMahon. 1987. Dispersal agents of vesicular-arbuscular mycorrhizal fungi in a disturbed arid ecosystem. Mycologia 79:721-730. 